\title{
A girl with short stature and dysmorphism
}

\author{
SW Cheng ${ }^{*}$, LK Lee, CY Lee \\ From 7th APPES Biennial Scientific Meeting \\ Nusa Dua, Bali. 14-17 November 2012
}

\section{Case presentation}

A 5-year-9month old Chinese girl presented with severe growth retardation, height SDS -4.17 and body weight SDS -2.37. The mid-parental height was $151.2 \mathrm{~cm}\left(3^{\text {rd }}-10^{\text {th }}\right.$ centile). She was born small for gestational age with no catch-up growth. Congenital anomalies including right dysplastic kidney and large secundum atrial septal defect were present. She had delayed development with microcephaly and dysmorphism, including triangular facies, epicanthic folds, low set ears, micronagthia, and brachydactyly. Ophthalmological assessment showed astigmatism, myopia, and left exotropia requiring surgical correction. Audiology assessment showed bilateral mild conductive hearing loss. Thyroid function, morning cortisol, serum calcium and renal function tests were normal. Metabolic disease workup including lactate, plasma for amino acid, urine metabolic screen, VLCFA, transferrin isoelectrofocusing and clotting profile were normal. CT and MRI brain were normal. Serum IGF- 1 at 13 years old was $62 \mathrm{nmol} / \mathrm{L}(+0.5 \mathrm{SD})$. Growth hormone study with glucagon showed peak growth hormone of $32 \mathrm{mg} / \mathrm{L}$. Bone age was 12 years at chronological age of 12-year-10month. Radiograph of both hands showed brachydactyly but no proximal implantation of $1^{\text {st }}$ digit. Genetic study show normal karyotype, but MLPA and FISH later confirmed heterozygous terminal deletion of 15q26.2 with the genetic defect compatible with IGF-1 receptor mutation. Growth hormone therapy was refused by the patient and mother. Breast development started at 12-year-4month and menarche started at 13-year-5month of age. The growth spurt was absent with peak growth velocity of only $5.5 \mathrm{~cm} /$ year. On the latest follow-up at 13-year-9month of age, her height was $128.8 \mathrm{~cm}(-4.7 \mathrm{SDS})$.

\section{Discussion}

Our patient displayed typical phenotypic features of IGF-1 receptor mutation of heterozygous deletion of $15 \mathrm{q} 26.2$ with severe growth retardation. The condition could

Caritas Medical Centre, Hong Kong potentially benefit from growth hormone treatment according to recent literatures [1]. Our report highlights the importance of investigating for genetic causes of short stature in patients with concomitant dysmorphism and growth retardation.

Published: 3 October 2013

\section{Reference}

1. Walenkamp Marie JE, de Muinck Keizer-Schrama Sabine MPF, de Mos Marianne, Kalf Margot E, van Duyvenvoorde Hermine A, Boot Annemieke M, Kant Sarina G, White Stefan J, Losekoot Monique, Den Dunnen Johan T, Karperien Marcel, Wit Jan M: Successful Long-Term Growth Hormone Therapy in a Girl with Haploinsufficiency of the Insulin-Like Growth Factor-I Receptor due to a Terminal 15q26.2->qter Deletion Detected by Multiplex Ligation Probe Amplification. 2008.

doi:10.1186/1687-9856-2013-S1-P42

Cite this article as: Cheng et al:: A girl with short stature and dysmorphism. International Journal of Pediatric Endocrinology 2013 2013(Suppl 1):P42.
Submit your next manuscript to BioMed Central and take full advantage of:

- Convenient online submission

- Thorough peer review

- No space constraints or color figure charges

- Immediate publication on acceptance

- Inclusion in PubMed, CAS, Scopus and Google Scholar

- Research which is freely available for redistribution

\section{() Biomed Central}

\section{() Biomed Central}

